\title{
INFLUENCE OF UNTREATED AND TREATED COIR PITH ON COMPACTION AND STRENGTH CHARACTERISTICS OF SOIL
}

\author{
Aiswarya T.S ${ }^{1}$, Deepthy B.L $\mathbf{L}^{2}$ \\ ${ }^{l}$ M Tech student, Dept. of Civil Engineering, Marian Engineering College, Kazhakuttom, Thiruvananthapuram, \\ Kerala \\ ${ }^{2}$ Assistant professor, Dept. of Civil Engineering, Marian Engineering College, Kazhakuttom, Thiruvananthapuram, \\ Kerala
}

\begin{abstract}
Scarcity of land has led to the improvement of ground by stabilisation so as to utilize the available land, which was once considered unsuitable for construction activities. Many studies have been carried out to improve the ground using natural and synthetic fibres. Industrial and agricultural wastes are used to stabilise the soil as they are easily available and cheap. This can reduce the pollution due to disposal of such wastes. In this study, coir pith is used to stabilise the soil. This paper studies the effect of untreated and untreated coir pith on the compaction and the shear strength characteristics of the soil mixed with coir pith in varying percentages of $0 \%$ to $3 \%$ with an increment of 0.5\%. A slight reduction in the dry density was observed with increase in percentage of coir pith. Whereas the treated coir pith soil mix shows increase in dry density as the pith content increases. It was observed that the optimum moisture content increases with increase in percentage of coir pith till $2 \%$ and thereafter decreases. For treated pith-soil mix, OMC decreases at first and then increases. A considerable increase in shear strength was observed after the chemical treatment of coir pith.
\end{abstract}

Keywords: Coir pith, Chemical treatment, Compaction, UCC

\section{INTRODUCTION}

Increase in population has increased the demand for land. Ground improvement becomes necessary at sites, where the soil available is weak. Many studies were conducted to improve the ground using natural and synthetic fibres. Therefore, researches have been carried out to utilize the industrial and agricultural wastes to stabilize the soils. The dumping of these wastes is a serious problem in the environment. The disposal of these wastes affects the environment. By utilizing these wastes as a stabilizer for soil, it improves the ground as well as reduces the pollution in the environment.

Silty soils are abundant in most parts of Kerala. Such soils are easily susceptible to settlement and shear failure. To stabilize such soils, coir pith is used in the present study. Coir pith is a byproduct of coir industry which is cheaper and easily available. According to the estimation of an exporting company (Vayalar exports), India produces about $2,80,000$ metric tons of coir fibre annually. Coir pith is a bio waste generated during the extraction of coir fibre from coconut husk. During the process of production of 1 ton of coir, approximately 2 tons of coir pith is produced [2]. Coir pith when disposed openly acts as a bacteria growing medium and results in poor hygiene of surrounding areas. When dumped into water bodies, it affects the aquatic life due to decay of coir pith [2]. This necessitates safe disposal of coir pith. In this paper, the coir pith is used to stabilise the silty soil. The variation in the compaction and shear strength characteristics are studied.

\section{MATERIALS}

\subsection{Soil}

Soil used in the present study is an inorganic silt of high compressibility (IS 1498-1970) obtained from Alappuzha. It was collected from a depth of $1 \mathrm{~m}$. Soil was partially air dried and powdered to a fraction less than $4.75 \mathrm{~mm}$. The physical properties of soil obtained are shown in the table 1 .

Table 1 Properties of soil

\begin{tabular}{|l|l|}
\hline Properties & Values \\
\hline Insitu water content (\%) & $163 \%$ \\
\hline Specific gravity & 2.53 \\
\hline Colour & Brown \\
\hline Plastic limit (\%) & $26.98 \%$ \\
\hline Liquid limit (\%) & $66 \%$ \\
\hline Shrinkage limit (\%) & $36.84 \%$ \\
\hline $\begin{array}{l}\text { Optimum moisture content } \\
(\%)\end{array}$ & $38.75 \%$ \\
\hline Maximum dry density (g/cc) & $1.17 \mathrm{~g} / \mathrm{cc}$ \\
\hline Soil classification & $\mathrm{MH}$ \\
\hline
\end{tabular}

\subsection{Coir pith}

Coir pith is collected from a coir manufacturing industry inVallakadavu. Coir pith obtained was sun dried and sieved through $4.75 \mathrm{~mm}$ sieve. The fraction which was passed through the sieve is taken for the study. The specific gravity of coir pith is 0.12 [5] and the average length of the fibre is $10 \mathrm{~mm}$. Chemical composition of coir fibre which is contained in coir pith is lignin $45.84 \%$, water soluble 
particles $5.25 \%$, pectin and related compounds $3.3 \%$, ash $2.22 \%$, hemi cellulose $0.25 \%$ [2]. Fig 1 shows the photograph of coir pith.

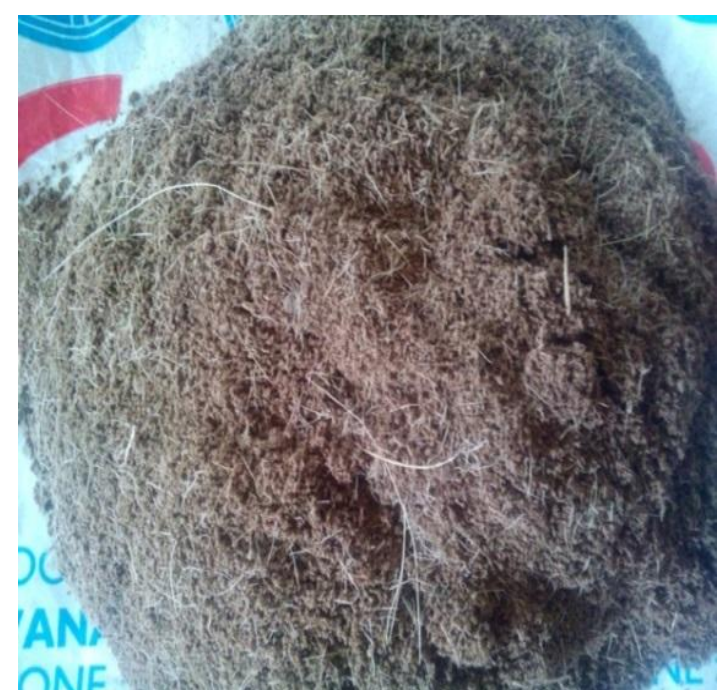

Fig 1 Coir pith

\section{METHODOLOGY}

The coir pith content was varied from $0 \%$ to $3 \%$ in increments of $0.5 \%$ by weight of the soil. Indian standard light compaction and unconfined compressive tests were performed on each soil-coir pith mix to determine the maximum dry density as well as the shear strength. For chemical treatment, $\mathrm{NaOH}$ at $5 \%$ concentration is used. Coir pith is soaked in 5\% concentration of $\mathrm{NaOH}$ solution for 1 hour room temperature followed by washing with water. Then, oven dried at $110^{\circ} \mathrm{C}$ for 2 hours. Then, again the tests were performed.

\section{RESULTS AND DISCUSSIONS}

\subsection{Untreated Coir Pith}

\subsubsection{Compaction Characteristics}

Indian standard light compaction tests were conducted with different percentages of coir pith. The tests were conducted as per IS-2720-part 7 (1980).

\subsubsection{Variation of Maximum Dry Density}

It is found that maximum dry density decreases with increase in the coir pith content. Maximum dry density was found to be $1.17 \mathrm{~g} / \mathrm{cc}$ for soil without fibre. With the addition of $0.5 \%$ coir pith, the maximum dry density decreases to $1.16 \mathrm{~g} / \mathrm{cc}$. When $3 \%$ fibre is added, the maximum dry density decreases to $1 \mathrm{~g} / \mathrm{cc}$. This is due to the replacement of soil with coir pith of specific gravity lower than the soil [2]. Fig 2 represents the variation of dry density with the fibre content.

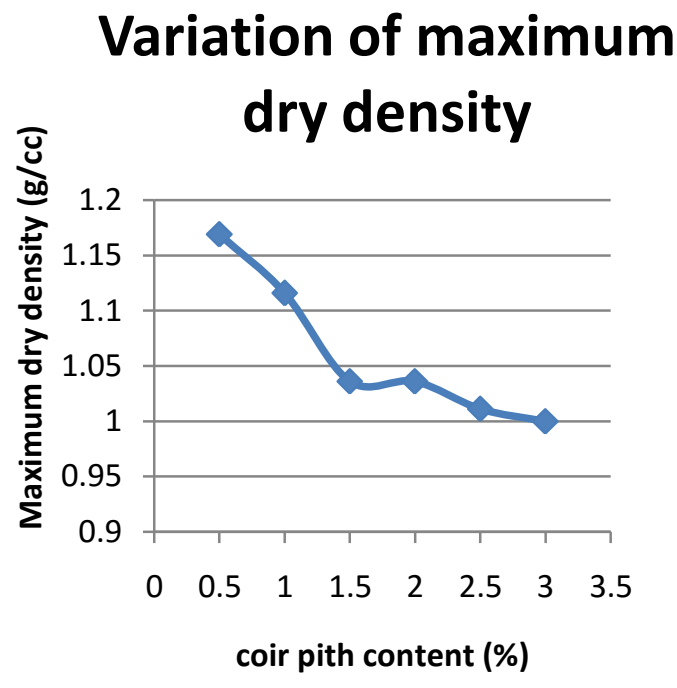

Fig 2 Variation of maximum dry density with coir pith content

\subsubsection{Variation of Optimum Moisture Content}

Fig 3 shows the variation of optimum moisture content with different percentage of coir pith. It is found that optimum moisture content increases upto $2 \%$ of coir pith and then decreases. The optimum moisture content for plain soil is $38.75 \%$ and increases to $52.88 \%$ with the addition of $2 \%$ of coir pith and then decreases to $46.36 \%$ with the addition of $3 \%$ of coir pith in the soil.

\section{Variation of OMC}

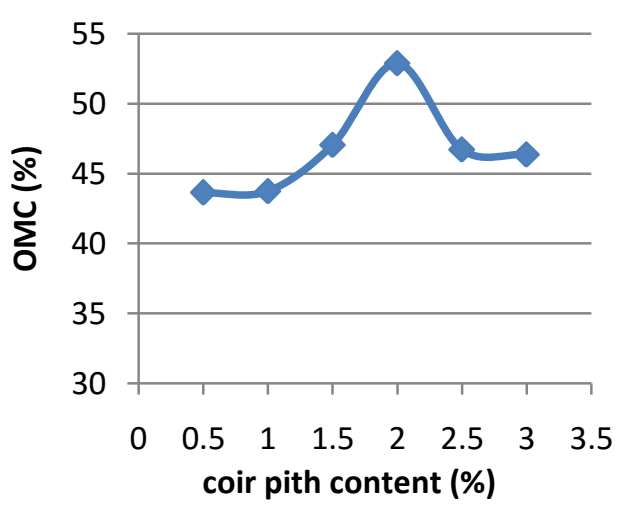

Fig 3 Variation of OMC with coir pith

\subsubsection{Shear Strength Characteristics}

The unconfined compressive tests were carried out as per IS-2720 - part 10 (1991) and unconfined compressive strength of each soil- coir pith mix is obtained. Bonding between the soil and fibre increases up to optimum content. When the fibre content increases after optimum content, there is a lack of proper bonding between the soil and fibre 
content. Fig 4 represents the variation of the shear strength due to the addition of varying percentages of coir pith. It shows that the UCC strength of the plain soil is $11.4 \mathrm{kN} / \mathrm{m}^{2}$ and increased to $22 \mathrm{kN} / \mathrm{m}^{2}$ by the addition of $1 \%$ coir pith. And then it decreases to $12.3 \mathrm{kN} / \mathrm{m}^{2}$ by the addition of $3 \%$ coir pith to soil. The maximum shear strength obtained is 11 $\mathrm{kN} / \mathrm{m}^{2}$ where as the shear strength of soil alone is found to be $5.7 \mathrm{kN} / \mathrm{m}^{2}$

\section{Variation of shear} strength

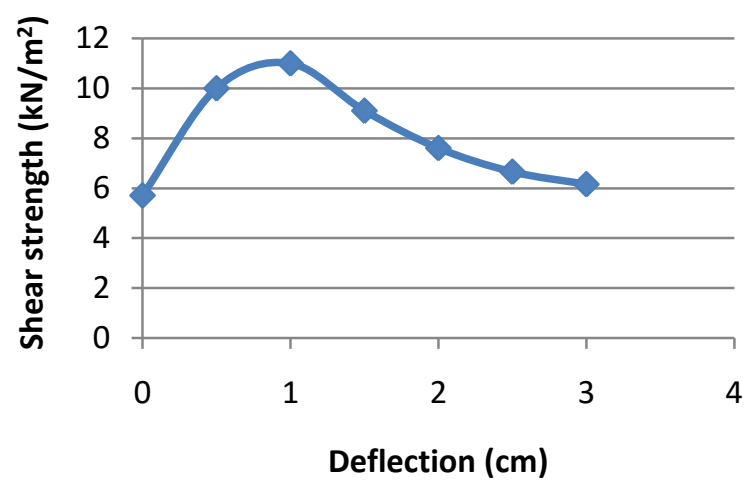

Fig 4 Variation of shear strength with coir pith content

\subsection{Treated Coir Pith}

\subsubsection{Compaction Characteristics}

\subsubsection{Variation of Maximum Dry Density}

It is found that maximum dry density increases with increase in the treated coir pith content. When $1 \%$ fibre is added, the maximum dry density increases to $1.162 \mathrm{~g} / \mathrm{cc}$. Fig 5 shows the variation of maximum dry density with varying treated coir pith content.

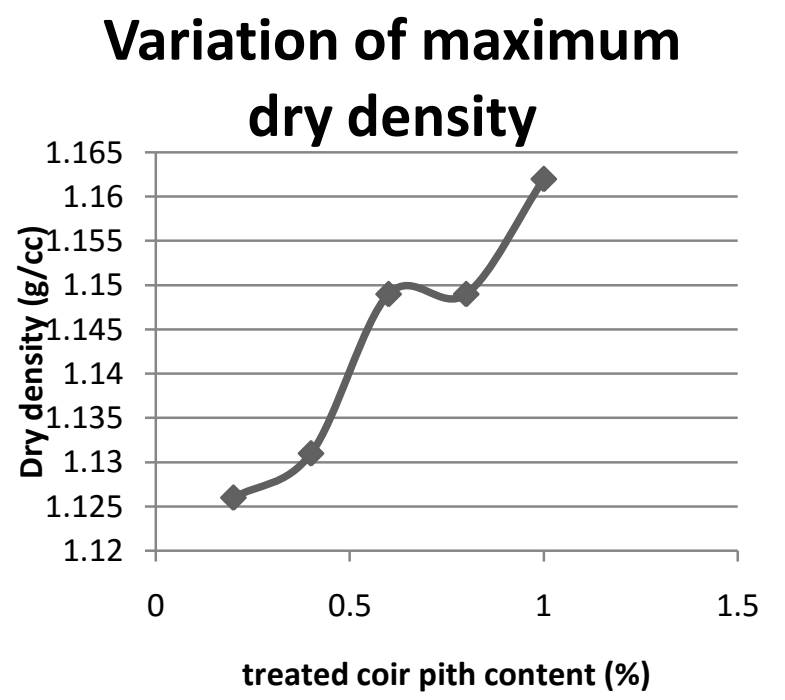

Fig 5 Variation of maximum dry density with treated coir pith content

\subsubsection{Variation of Optimum Moisture Content}

The OMC of soil specimen decreases upto $1.5 \%$ of treated coir pith and then increases to $39.144 \%$. Fig 6 shows the variation of optimum moisture content with different percentage of treated coir pith.

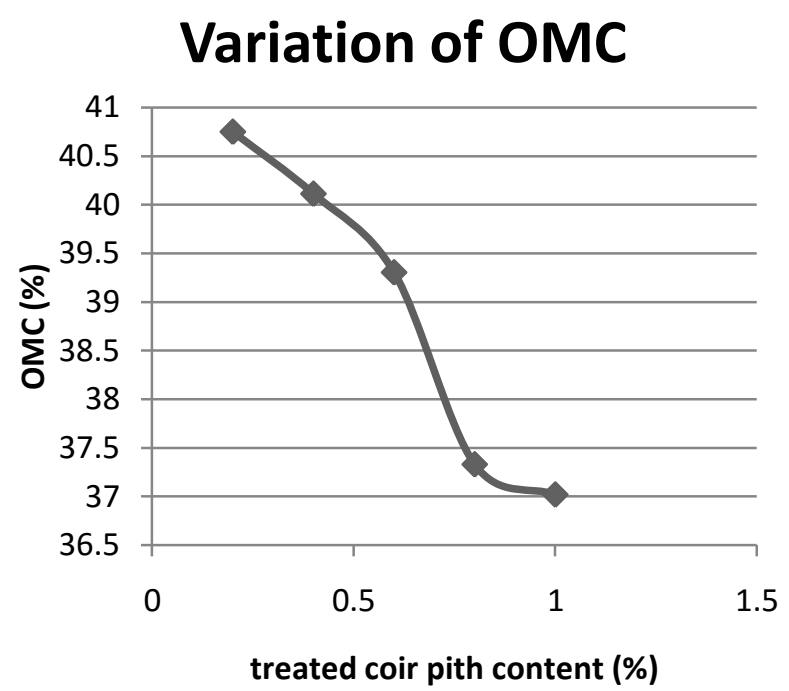

Fig 6 Variation of optimum moisture content with treated coir pith

\subsubsection{Shear Strength Characteristics}

Fig 7 represents the variation of the shear strength due to the addition of varying percentages of treated coir pith. Bonding between the soil and fibre increases up to optimum content. When the fibre content increases after optimum content, there is a lack of proper bonding between the soil and fibre content. Thereafter, the value decreases. The maximum UCS value obtained at $1.5 \%$ addition of treated coir pith, i.e., $36.83 \mathrm{kN} / \mathrm{m}^{2}$. The maximum shear strength obtained is $18.415 \mathrm{kN} / \mathrm{m}^{2}$.

\section{Variation of shear strength}

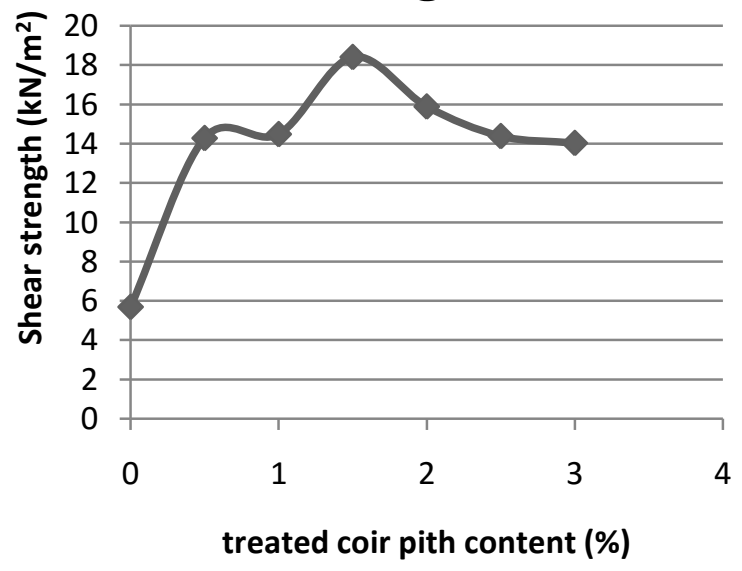

Fig 7 Variation of shear strength with treated coir pith 


\subsection{Comparison of Shear Strength}

The soil-treated pith mix shows higher shear strength than the soil-untreated pith mix The shear strength of soil-treated coir pith shows $67.4 \%$ increase than untreated one. Fig 8 shows the comparison of shear strength of treated and untreated coir pith soil mix.

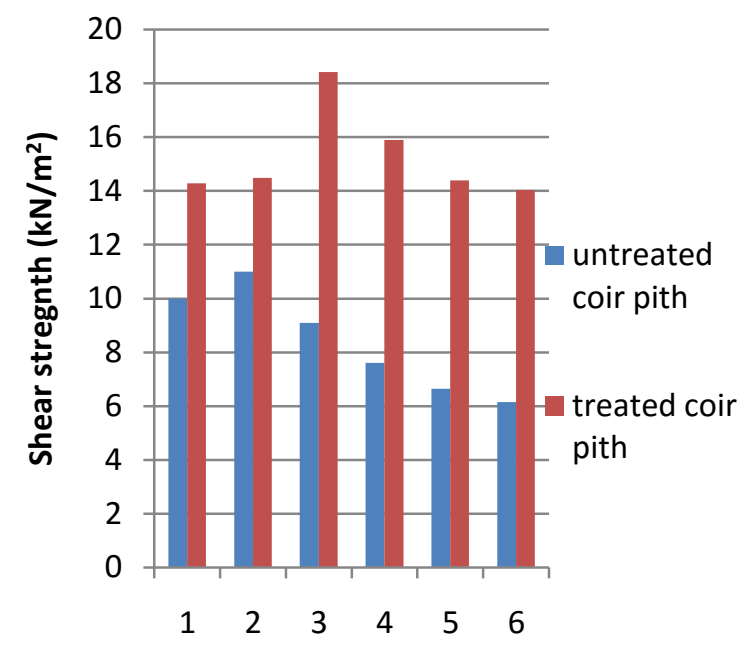

Fig 8 Comparison of shear strength of treated and untreated coir pith-soil mix

\section{CONCLUSION}

As the untreated coir pith content increases, the maximum dry density decreases. This is due to the replacement of soil with coir pith of specific gravity lower than the soil. Whereas, the maximum dry density increases with increase in the treated coir pith content. Optimum moisture content increases up to $2 \%$ of untreated coir pith i.e., $52.88 \%$ and then decreases. Whereas, the OMC of treated pith-soil specimen at first decreases and then increases to $39.144 \%$.UCC strength of the plain soil is $11.4 \mathrm{kN} / \mathrm{m}^{2}$ and it increases to $22 \mathrm{kN} / \mathrm{m}^{2}$ with the addition of $1 \%$ coir pith. The maximum shear strength obtained is $11 \mathrm{kN} / \mathrm{m}^{2}$ where as the shear strength of soil alone is found to be $5.7 \mathrm{kN} / \mathrm{m}^{2}$. The maximum UCS value obtained at $1.5 \%$ addition of treated coir pith, i.e., $36.83 \mathrm{kN} / \mathrm{m}^{2}$. The maximum shear strength obtained is $18.415 \mathrm{kN} / \mathrm{m}^{2}$. The shear strength of soil-treated coir pith shows $67.4 \%$ increase than untreated one.

\section{REFERENCES}

[1] Ankita, P.P., Bahera, D., Bastia, T.K., and Rath, P., (2013), "Characterization of Coir/Pith/Jute Fiber/Bisgma Hybrid Composites", International Journal of Advanced Chemical Science and Applications, 1(1), 2347-7601.

[2] Beena K.S., and Santhosh, G., (2013), "Studies on strength characteristics of soil mixed with biowaste", Proceedings of Indian Geotechnical Conference, 22-24.
[3] Bindu, J., and Ramabhadhran, A., (2013), "Studies on cement stabilized Kuttanad clay", Proceedings of Indian Geotechnical Conference, 222-230.

[4] Greeshma, P.G., and Joseph. M, (2011), "Rice straw reinforced for improvement in Kuttanad clay", Proceedings of Indian Geotechnical Conference,1517.

[5] Jayasree, P.K., Balan, K., Peter L., and Nisha, K. K.,(2013), "Influence of coir pith on swelling and shrinkage characteristics of expansive soil",Proceedings of Indian Geotechnical Conference, 22-24.

[6] Rakesh K., Obrai, S., and Sharma A., (2011), "Chemical modifications of natural fiber for composite material" Der chemical sinica, 2(4), 219228 . 